\title{
Influence of the probiotic bacterial strain, Bacillus cereus var. toyoi, on the development of selected microbial groups adhering to intestinal mucosal tissues of piglets ${ }^{*}$
}

\author{
A. Jadamus, W. Vahjen and O. Simon \\ Institute of Animal Nutrition. Free University of Berlin \\ Brüemmerstrasse 34, 14195 Berlin. Germany \\ (Received 29 September 1999; accepted 8 May 2000)
}

\begin{abstract}
The influence of the probiotic bacterial strain, Bacillus cereus var. toyoi, on the development of total anaerobic growth, enterobacteria, lactic acid bacteria, and Enterococcus spp. associated with intestinal mucosal tissues of piglets before and shortly after weaning was evaluated. Bacterial growth capacities were determined in microtiter plates by incubating mucosal tissue extracts in sclective liquid media for enterobacteria, lactic acid bacteria $(\mathrm{L} A \mathrm{~B})$, Enterococcus spp. or total anaerobic growth.

Growth of mucosa-associated enterobacteria was reduced $(\mathrm{P}<0.05)$ in samples from the trial group before weaning. Furthermore, growth was similar in all samples, while growth of enterobacteria from the control group increased the closer the samples were taken from the large intestine. Total anacrobic bacteria showed similar development as enterobacteria. Decreased growth was recorded in samples from the small intestine of piglets from the control group at the time of weaning at $28 \mathrm{~d}$ of age. Growth of Enterococcus spp. and LAB decreased from d 13 of age and displayed a sharp increase after weaning, independent of probiotic supplementation.

It is concluded that $B$. cereus var. toyoi depressed growth of enterobacteria in the intestinal tract. There are strong indications that the early uptake of already modified microbial populations from faeces of the sow aids in the establishment of similar microbial populations in the piglet.
\end{abstract}

KEY WORDS: probiotic, Bacilhs cereus var. toyoi, gastrointestinal tract, mucosal tissue, growth behaviour, piglet

* Supported by Lohman Animal Health, Cuxhaven, Germany 


\section{INTRODUCTION}

Probiotics are viable microorganisms, which are believed to modify the ecology of the intestinal tract in a manner beneficial for the host (Fuller, 1992). Their physiological function in the intestinal tract is not well understood and mechanisms of probiotic action are still a matter of speculation. The origin of probiotics (yeast, soil bacteria, intestinal bacteria) is highly diverse and thus several probiotic mechanisms must be responsible for positive effects. Probiotics have become popular as feed additives in animal nutrition as a response to increased public pressure against antibiotics in feed. These so-called growth promoters have been used with much success in animal nutrition. It has been shown that probiotics can be as effective as growth promoters in terms of liveweight gain, feed conversion efficiency and prevention of diarrhoea (Iben and Leibetseder, 1989). However, positive effects $(P<0.05)$ on performance parameters are not always observed under defined experimental conditions (Nousiainen and Setälä, 1993). Benefits are not found when piglets are reared under excellent hygienic conditions (Fuller, 1999). Thus, it is conceivable that the hygienic conditions of controlled studies on the effects of probiotic preparations sometimes do not reflect those that are encountered in intensive pig farming.

Eleven probiotic preparations are approved in the European Union for use in animal nutrition (Statutory Regulations for Feedstuffs, 1999). Most preparations include yeast (Saccharomyces cerevisiae) and bacteria from the intestinal tract, such as Enterococcus faecium, but there are also preparations containing the soil bacterium Bacillus spp. as an active ingredient.

Bacillus spp. are motile, facultativcly anacrobic spore-forming bacteria, which are able to grow in the intestinal tract of mammals and avian species. Germination of $B$. cereus var. toyoi, for instance, occurs within $10 \mathrm{~min}$ in growth media. Our own observations with $B$. cereus var. toyoi confirm intensive germination of spores in in vitro studies with samples from the intestinal tract of piglets and broilers (Jadamus et al., 1998a,b).

B. cereus var. toyoi, strain T 7112 (ToyoCerin, manufacturer Asahi Vet. S. A., Tokyo, Japan) has been used for over 20 years as a probiotic preparation in animal nutrition (Kahrs, 1986). Its beneficial effects are expected to be attributed to the exclusion of enterobacteria (Hattori and Watanabe, 1981), reduction of diarrhoea and decreased mortality of piglets after weaning. B. cereus var. toyo $i$ has been shown to influcnce populations of enterobacteria, but its basic mechanisms have yet to be detcrmined.

Sequential colonization of the pig intestine with different microorganisms starts shortly after farrowing. Lactic acid bacteria are the dominant bacteria in newborn piglets (Smith and Jones, 1963), but factors like increased immune response from the host, bacterial competition (Savage, 1977) and morphological 
changes in the gastrointestinal tract lead to the development of complex bacterial populations.

Bacterial communities from environmental samples are usually analyzed by colony forming units (CFU) after cultivation of sample dilutions on solid media, which allow growth of all bacteria or growth of certain bacterial groups such as lactic acid bactcria, enterobacteria or enterococci. The most probable number method can also be used. It calculates bacterial numbers after cultivation of highly diluted samples in liquid media. A similar approach has been employed in this study. In order to reduce time on hand and material use, a microtiter format was chosen to record bacterial growth after cultivation of sample dilutions in fluid media to determine both multiplication in mucosal samples and growth behaviour during incubation.

This study was carried out in an attempt to gain more data on the influence of $B$. cereus var. toyoi on sclected microbial populations in the intestinal tract of piglets.

\section{MATERIAL AND METHODS}

\section{Animals and diets}

Six sows were divided into two groups 14 days before farrowing and fed diets either supplemented or not with ToyoCerin, obtained from Lohmann Animal Health, Cuxhaven (Germany) ( $10^{9}$ spores $/ \mathrm{kg}$ feed) (Table 1). Depending on the the feed received by the sow, 14-day-old suckling piglets had ad libitum access to creep feed supplemented or not with ToyoCerin $\left(10^{9}\right.$ spores $/ \mathrm{kg}$ fecd $)$. After weaning at $28 \mathrm{~d}$ of age the piglets were transferred to flatdecks and fed a starter diet with or without the probiotic strain.

\section{Sampling and cultivation}

Three piglets from each trial group werc killed with T61 (Hoechst-Roussel Vet., Frankfurt, Germany) intracardial after sedation with Stresnil (Janssen-Cilag, Neuss, Germany) at 13,21,28 and $32 \mathrm{~d}$ of age. Tissue samples of the duodenum (divided into two equal parts), jejunum (divided into three equal parts), ilcum (divided into two equal parts), caecum and colon wore washed for $30 \mathrm{~min}$ in a minimal medium $\left(\mathrm{Na}_{2} \mathrm{HPO}_{4} \times 12 \mathrm{H}_{2} \mathrm{O}, 15 \mathrm{~g} \mathrm{l}^{-1} ; \mathrm{KH}_{2} \mathrm{PO}_{4}, 3 \mathrm{~g} \mathrm{l}^{-1} ; \mathrm{NaCl}, 1 \mathrm{gl}^{-1}\right.$; $\mathrm{NH}_{4} \mathrm{Cl}, 1 \mathrm{gl}^{-1}$; L-methionine, $80 \mathrm{mg} \mathrm{l}^{-1}$; L-cysteine, $0.5 \mathrm{~g} \mathrm{l}^{-1}$; Na-formaldehydsulphoxylate, $0.3 \mathrm{~g} \mathrm{l}^{-1}$; hemin solution, $10 \mathrm{mg} \mathrm{l}^{-1}$; vitamin $\mathrm{K}_{1}, 4 \mathrm{mg} \mathrm{l}^{-1}$ ) at $4^{\circ} \mathrm{C}$ with shaking at $5 \mathrm{~min}$ intervals. Mucosal tissue was then removed with sterile scalpels. 
TABLE 1

Formulation and partial chemical composition of the diets

\begin{tabular}{|c|c|c|c|}
\hline Components, $\mathrm{g} / \mathrm{kg}$ & $\begin{array}{l}\text { Sow } \\
\text { diet }\end{array}$ & $\begin{array}{l}\text { Creep feed for } \\
\text { suckling piglets }\end{array}$ & $\begin{array}{l}\text { Starter diet } \\
\text { for piglets }\end{array}$ \\
\hline ToyoCerin $\left(10^{4}\right.$ spores $/ \mathrm{kg}$ feed $)$ & + & + & + \\
\hline Barley & 379 & - & - \\
\hline Wheat & 360 & 527.53 & 646.11 \\
\hline Soya extraction meal & 180 & 270 & 260 \\
\hline Soya oil & 30 & 25 & 25 \\
\hline Wheat bran & - & 15 & 20 \\
\hline Milk powder & - & 120 & - \\
\hline Vitamin-mineral premix * & 20 & 15 & 13 \\
\hline Cephcaphos $* *$ & 7 & - & 13.9 \\
\hline Dicalcium phosphate & - & 12.94 & - \\
\hline Limestone & 18 & 9.97 & 17.2 \\
\hline L-lysine & 4 & 1.83 & 2.61 \\
\hline DL-methionine & 1 & 1.61 & 1 \\
\hline Tryptophan & - & 0.72 & 0.57 \\
\hline Threonine & 1 & - & 0.08 \\
\hline Optifac-Duplex*** & - & 0.4 & 5.6 \\
\hline $\mathrm{TiO}_{2}$ & 5 & 5 & 5 \\
\hline \multicolumn{4}{|c|}{ Anatysed nutrient and energy composition, $\mathrm{g} / \mathrm{kg}$} \\
\hline dry matter & 900.8 & 905.1 & 901.3 \\
\hline metabolisable energy, $\mathrm{MJ} / \mathrm{kg}$ & 13.4 & 13.9 & 13.6 \\
\hline crude protein & 198.6 & 234.6 & 202.3 \\
\hline crude lat & 23.9 & 18.8 & 41.5 \\
\hline crude fibre & 47.8 & 38 & 36.9 \\
\hline
\end{tabular}

* contents in $1 \mathrm{~kg}: 1200.000 \mathrm{lE}$ Vit. A, $120.000 \mathrm{IE}$ Vit. D, $4.000 \mathrm{mg}$ Vit. E, $200 \mathrm{mg}$ Vit. B, $600 \mathrm{mg}$ Vi1. $\mathrm{B}_{2}, 2.500 \mathrm{mg}$ niacin. $400 \mathrm{mg}$ Vit. $\mathrm{B}_{f}, 4500 \mu \mathrm{g}$ Vit $\mathrm{B}_{12}, 20.000 \mu \mathrm{g}$ biotin, $1800 \mathrm{mg}$ pantothenic acid, $160 \mathrm{~g} \mathrm{Na}, 50 \mathrm{~g} \mathrm{Mg}, 10.000 \mathrm{mg} \mathrm{Zn,} 7.500 \mathrm{mg} \mathrm{Fe}, 7.500 \mathrm{mg} \mathrm{Mn}, 150 \mathrm{mg} \mathrm{J}$, $70 \mathrm{mg}$ Co. $40 \mathrm{mg} \mathrm{Se}$

** monocalciumphosphate

$* * *$ seasoning mixture

Determination of bacterial growth capacities

Microtiter plates (Greiner, Frickenhausen, Germany) were filled with $180 \mu \mathrm{l}$ nonselective nutrient broth ( $4 \mathrm{~g} \mathrm{l}^{-1}$ glucose, $2.5 \mathrm{~g} \mathrm{l}^{-1}$ meat extract, $2.5 \mathrm{~g} \mathrm{l}^{-1}$ proteose peptone, $\mathrm{I} \mathrm{g} \mathrm{l}^{-1}$ yeast extract, $1 \mathrm{~g} \mathrm{l}^{-1}$ lyophilized raw mucin from pigs, $\mathrm{pH} 7$ ), selective broth for Enterococcus spp. $\left(2 \mathrm{~g} \mathrm{l}^{-1}\right.$ glucose, $5 \mathrm{~g} \mathrm{l}^{-1}$ yeast extract, $40 \mathrm{~g} \mathrm{l}^{-1}$ tryptose, $4 \mathrm{~g} \mathrm{l}^{-1} \mathrm{Na}_{2} \mathrm{HPO}_{4} \times 1 \mathrm{H}_{2} \mathrm{O}, 40 \mathrm{~g} \mathrm{l}^{-1}$ oxbile, $0.4 \mathrm{~g} \mathrm{l}^{-1} \mathrm{Na}$-azide, $0.1 \mathrm{~g} \mathrm{l}^{-1}$ triphenyltetrazoliumchloride, $\mathrm{pH} 7$ ), modified MRS-broth (4 $\mathrm{g}^{-1}$ glucose, $2.5 \mathrm{~g} \mathrm{l}^{-1}$ meat 
extract, $2.5 \mathrm{~g} \mathrm{l}^{-1}$ proteose peptone, $1 \mathrm{~g}^{1^{-1}}$ yeast extract, $0.2 \mathrm{~g} \mathrm{l}^{-1}$ tween $80,0.2 \mathrm{~g} \mathrm{l}^{-1} \mathrm{di}^{-}$ ammoniumhydrogencitrate, $1 \mathrm{~g} \mathrm{l}^{-1} \mathrm{Na}$-acetate, $0.025 \mathrm{~g} \mathrm{l}^{-1} \mathrm{MgSO}_{4}, 0.01 \mathrm{~g} \mathrm{l}^{-1} \mathrm{MnSO}_{4}$, $0.4 \mathrm{~g} \mathrm{l}^{-1} \mathrm{Na}_{2} \mathrm{HPO}_{4} \times 1 \mathrm{H}_{2} \mathrm{O}, \mathrm{pH}$ 5.6) for lactic acid bacteria (LAB) and modificd McConkey-broth (17 $\mathrm{g} \mathrm{l}^{-1}$ peptone, $3 \mathrm{~g} \mathrm{l}^{-1}$ proteose peptone, $10 \mathrm{~g} \mathrm{l}^{-1}$ lactose, $5 \mathrm{~g} \mathrm{l}^{-1}$

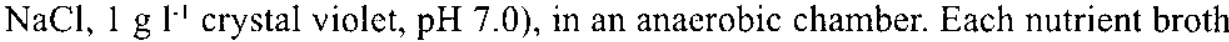
included $1 \mathrm{~g} \mathrm{l}^{-1} \mathrm{MgSO}_{4}(1 \mathrm{M}), 1 \mathrm{~g} \mathrm{l}^{-1}$ thiamine, $5 \mathrm{~g} \mathrm{l}^{-1} \mathrm{NAD}, 1 \mathrm{~g} \mathrm{l}^{-1}$ trace elements, $4 \mathrm{~g} \mathrm{l}^{-1} \mathrm{Ca}$-pantothenate, $10 \mathrm{~g} \mathrm{l}^{-1}$ myo-inositol, $0.1 \mathrm{~g} \mathrm{l}^{-1} \mathrm{CaCl}_{2}(1 \mathrm{M})$ and $0.005 \mathrm{~g} \mathrm{l}^{-1}$ biotin. Decimal dilutions of mucosal tissues from both parts of the duodenum, the second part of the jejunum and ileum, caecum and colon were then applied in triplicate $(20 \mu \mathrm{I})$ and the plates were incubated at $37^{\circ} \mathrm{C}$ for 24 to $48 \mathrm{~h}$ under anaerobic conditions. Microbial growth was detected as turbidity at $690 \mathrm{~nm}$ in a microtiter reader (Dynatech MR 7000, Denkendorf, Germany). Nutrient broth inoculated with the dilution solution served as control wells. The outer rows were only inoculated with nutrient broth to reduce vapor losses during incubation. A total of 18 wells were used to calculate mean values of absorption readings for each sample in the respective nutrient broth.

\section{Statistical analysis}

Data are presented as arithmetic means with standard deviations. Analysis of variance and Student's $t$ test $(\mathrm{P}<0.05,0.01$ and 0.001$)$ were performed to determine differences in bacterial growth capacitics.

\section{RESULTS}

\section{Total anaerobic growth}

Total anaerobic bacteria from samples of the intestinal tract of suckling piglets with probiotic-fed sows usually showed higher growth capacities compared to the control piglets (Figure 1A). One week after the first intake of creep feed, a sharp increase of total anacrobic growth was detected in both experimental groups (Figure 1B). Samples from mucosal tissues of the large intestine of probiotic-fed piglets showed less growth $(\mathrm{P}<0.01)$ compared to samples of piglets fed diets without ToyoCerin. At the time of weaning, growth capacities in samples from piglets with access to $B$. cereus var. toyoi feed remained nearly constant throughout the intestine, but growth capacities from the control group increased the closer the samples had been taken to the large intestine (Figurc 1C). Four days after weaning, sharply increased growth occurred in all samples from small intestinal segments of piglets fed diets without ToyoCerin, while total anaerobic growth from samples of the large intestine seemed to be less affected by weaning (Figure 1D). 

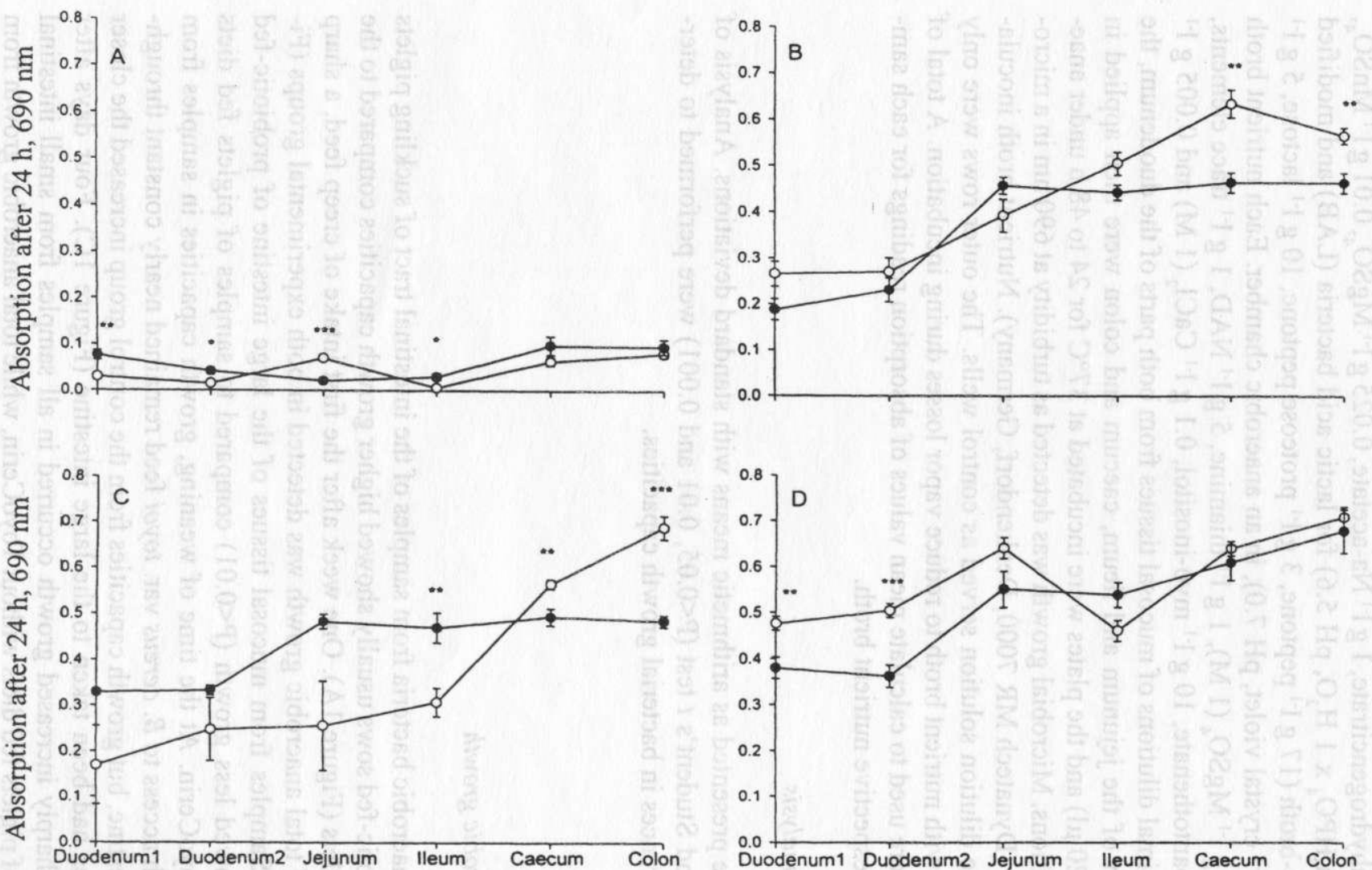

Figure 1. Development of total anaerobic bacteria growth capacities in mucosal tissue samples from piglets $\mathrm{O}=$ unsupplemented feed; $\bullet=B$. cereus var. toyoi supplemented feed $\left(10^{9}\right.$ spores $/ \mathrm{kg}$ feed $) \mathrm{A}=$ suckling piglets ( 13 days old $), \mathrm{B}=$ one week after the first intake of creep feed $(21$ days old), $\mathrm{C}=$ time of weaning ( 28 days old), $\mathrm{D}=$ four days after weaning (32 days old). ${ }^{*}$ significant differences between piglets with or without ToyoCerin supplementation (Student's $t$-test, $\mathrm{P}<0.05,{ }^{* *} \mathrm{P}<0.01,{ }^{* * *} \mathrm{P}<0.001$ ) 
Lactic acid bacteria (LAB) and Enterococcus spp.

In contrast to growth of total anaerobic bacteria, growth capacities of $\mathrm{LAB}$ (Figure 2) and enterococci (Figure 3), as well as enterobacteria (see below), decreased until weaning in samples from the control group and increased sharply after weaning in most intestinal segments. Probiotic supplementation led to a similar growth increase after weaning. While growth of LAB (Figurc $2 \mathrm{C}$ ) and enterococci (Figure $3 \mathrm{C}$ ) in samples from the control group showed the lowest growth on the day of weaning, growth of LAB and enterococci from piglets with probiotic-supplemented diets had already increased in most samples shortly before weaning.

\section{Enterobacteria}

Suckling piglets from probiotic-fed sows showed less $(\mathrm{P}<0.05)$ and more homogenous growth of mucosa-associated enterobacteria compared with piglets from sows fed the unsupplemented diet (Figure 4A). On d 21 of age, homogenous growth was again observed in samples from piglets with access to probiotic-supplemented feed (Figure 4B), but continuously increasing growth throughout the intestine was found in samples from the control group.

At the time of weaning (d 28), probiotic-supplemented piglets showed higher enterobactcrial growth in all intestinal segments except in the colon, but again on a similar level, while growth in samples of the control group increased throughout the intestinal tract (Figure 4C). Four days after weaning, piglets from both experimental groups showed increased growth with fewer differences between piglets fed probiotic-supplemented and unsupplemented diets (Figure 4D).

The same effect, as observed for enterococci and LAB in the respective experimental groups, was also found for enterobacteria. While growth of enterobacteria decreased in the control group until the time of weaning, enterobacterial growth in samples from the probiotic-fed group had already increased at $\mathrm{d} 21$ of age.

Two major effects of probiotics were detected: (1) a significant decrease of enterobacterial growth in samples from the intestinal tract until d 21 of age and similar growth capacities in all samples until weaning; (2) growth capacities of LAB, Enterococcus spp. and enterobacteria in samples of the probiotic-supplemented experimental group tended to already increase on $\mathrm{d} 21$ of age, while respective growth in the control group increased sharply after weaning. 

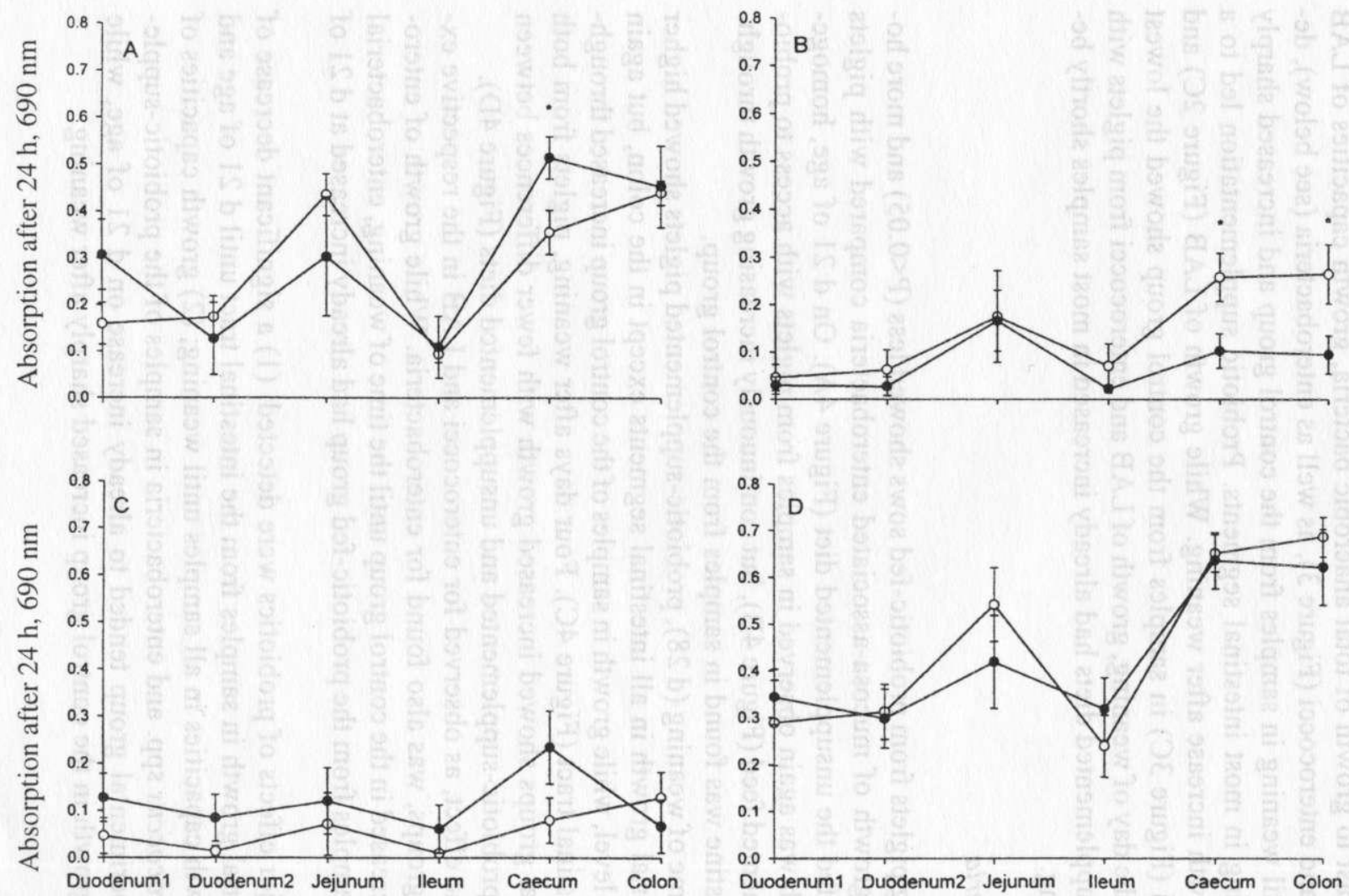

Figure 2. Development of $\mathrm{LAB}$ growth capacities in mucosal tissue samples from piglets. $\mathrm{O}=$ unsupplemented feed; $\bullet=B$. cereus var. toyoi supplemented feed $\left(10^{9}\right.$ spores $/ \mathrm{kg}$ feed) $\mathrm{A}=$ suckling piglets ( 13 days old $), \mathrm{B}=$ one week after the first intake of creep feed $(21$ days old $), \mathrm{C}=$ time of weaning ( 28 days old), $\mathrm{D}=$ four days after weaning ( 32 days old). * significant differences between piglets with or without ToyoCerin supplementation (Student's $t$-test, $\mathrm{P}<0.05,{ }^{* * *} \mathrm{P}<0.001$ ) 

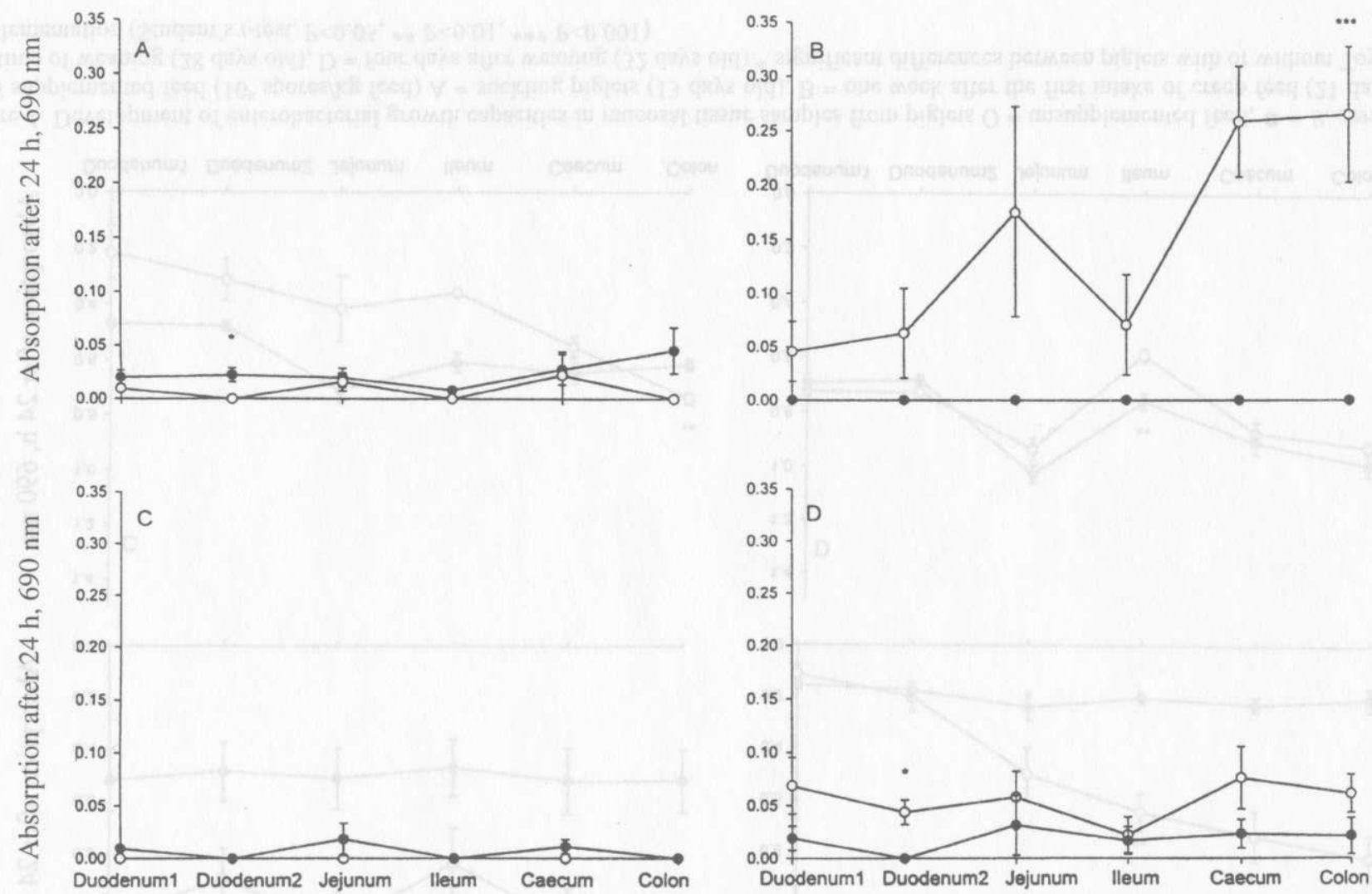

Figure 3. Development of Enterococcus spp. growth capacities in mucosal tissue samples from piglets $\mathrm{O}=$ unsupplemented feed; $\bullet=B$. cereus var. toyoi supplemented feed $\left(10^{9}\right.$ spores $/ \mathrm{kg}$ feed) $\mathrm{A}=$ suckling piglets (13 days old), B = one week after the first intake of creep feed ( 21 days old), $\mathrm{C}=$ time of weaning ( 28 days old), $\mathrm{D}=$ four days after weaning ( 32 days old). ${ }^{*}$ significant differences between piglets with or without ToyoCerin supplementation (Student's $t$-test, $\mathrm{P}<0.05$ ) 

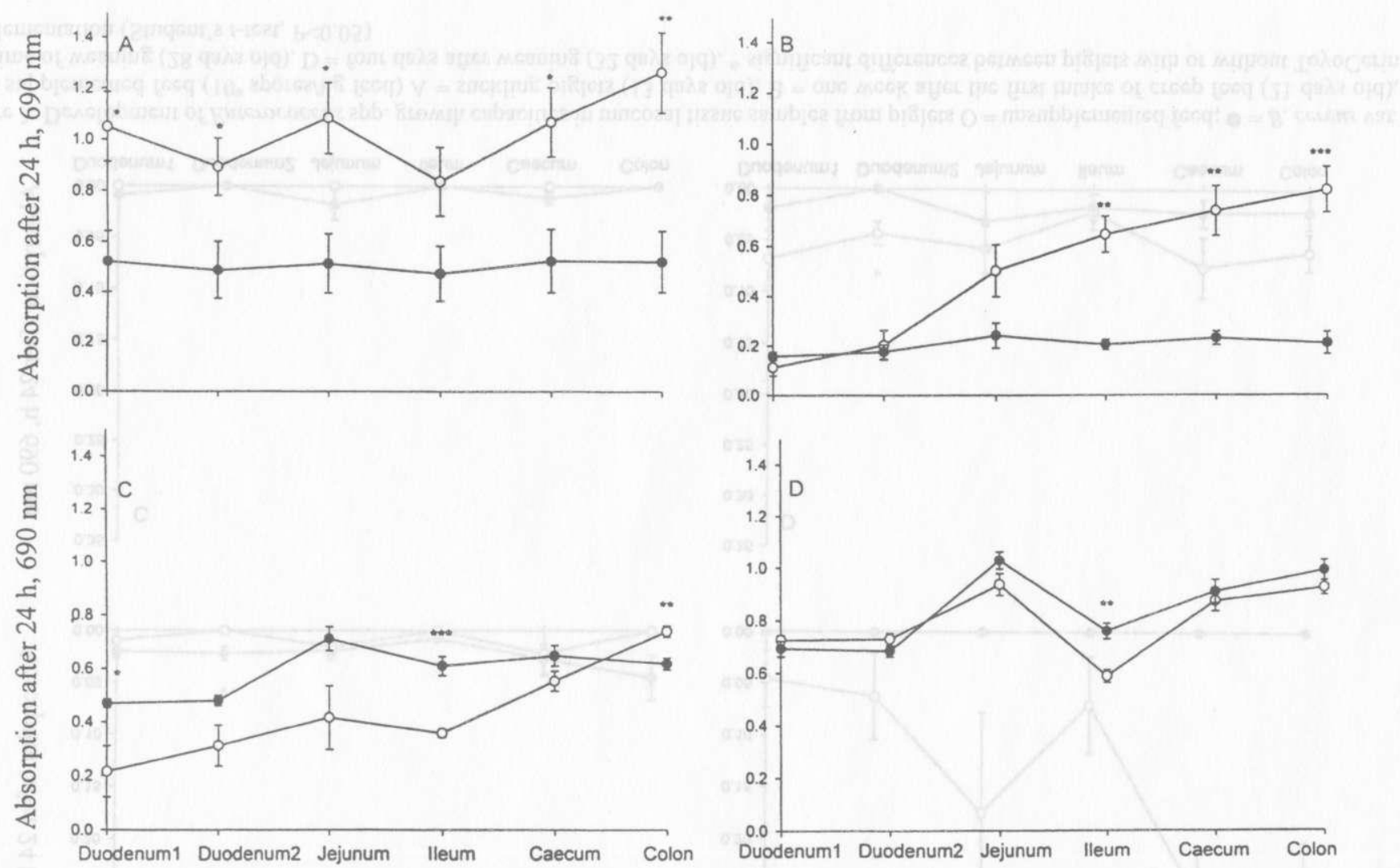

Figure 4. Development of enterobacterial growth capacities in mucosal tissue samples from piglets $\mathrm{O}=$ unsupplemented feed; $\bullet=B$, cereus var. toyoi supplemented feed $\left(10^{9}\right.$ spores $/ \mathrm{kg}$ feed) $\mathrm{A}=$ suckling piglets (13 days old), B = one week after the first intake of creep feed ( 21 days old), $\mathrm{C}=$ time of weaning ( 28 days old), $\mathrm{D}=$ four days after weaning $(32$ days old).* significant differences between piglets with or without ToyoCerin supplementation (Student's $t$-test, $\mathrm{P}<0.05,{ }^{* *} \mathrm{P}<0.01,{ }^{* * *} \mathrm{P}<0.001$ ) 


\section{DISCUSSION}

Growth of bacteria occurred in all media, but differed in mean absorption values. The nutrient broth for Enterococci displayed the weakest absorption values (maximum at $0.08 \mathrm{~A}_{690}$ ) because of its selectivity towards enterococci. The nutrient broth for $\mathrm{LAB}$ and even more for the medium for total anaerobic growth offered a less selective environment with wider arrays of complex nutrients and thus, higher absorption values were observed. The highest growth capacities were noticed for the endo broth (maximum at $1.3 \mathrm{~A}_{690}$ ). Enterobacteria are known for their rapid growth in nutrient media and growth probably reached a stationary phase within the incubation period.

The washing procedure removed most bacteria that did not actively adhere to mucosal tissues or were trapped within the mucin layer, and it can be assumed that the majority of bacteria in the sample had adhering capabilities. Adherence involves production of proteinaccous cell components (Wibawan et al., 1992; Knutton et al., 1999) or carbohydrate moieties on the cell wall (Wadstrom et al., 1987) and subsequently formation of microcolonies on host cell surfaces (Holt and Krieg, 1994; Costerton et al., 1999). These cell aggregates can not be completely dispersed without severe extraction procedures, which will consequently reduce the viability of the entire bacterial population under study. Thus, incomplete dispersal, but homogeneous distribution of bacterial aggregates in diluted samples may have occurred during extraction and dilution. Bacteria were probably incubated as aggregates and interaction within the developing microcolony as noticed for Pseudomonas aeruginosa (Davies et al.. 1998) could be a possible explanation for non-linear growth. Visual observation of microtiter plate wells after incubation showed distinct structures of microbial growth in media for $\mathrm{LAB}$ and total anaerobic growth. These structures were destroyed by shaking prior to turbidity readings. It can be argued that higher dilutions carried an insufficient number of bacterial aggregates and thus the positive cooperation required for developing microcolonies was below a threshold for significant growth. Positive cooperation in intestinal adhesion has been observed for Lactobacillus fermentum (Rojas and Conway, 1996) and may be an underlying mechanism for intestinal colonization (Van der Mei et al., 1993).

It was concluded that data from the method used can be regarded as an expression of growth capacities of existing microbial populations in mucosal tissues of piglets. The low selectivity of the MRS medium (detection of LAB) may have allowed growth of other bacteria, which thrive under more acidic conditions ( $\mathrm{pH}$ 5.6). However, growth of total anaerobic bacteria or enterobacteria progressed differently than growth of LAB. Furthermore, growth of enterococci, also belonging to the LAB group, was similar to that in the MRS broth. It was thus assumed that the bias introduced by growth of bacteria other than lactic acid bacteria was low in the employed modified MRS broth. 
The observed growth can not be directly compared with CFU, because growth on solid media isolates bacterial populations and thus interactions between bacteria are excluded, except for competition between bacteria within a developing colony. Cultivation in liquid media leads to the enrichment of a group of bacteria which thrive especially well in their respective media (Gerhardt et al., 1994). The measurement of growth and consequently turbidity is biased by interaction between different bacteria during cultivation and by the initial amount of viable bacterial cells. This effect is especially important when comparing probiotic influences on intestinal bacteria, as the probiotic is also present and may act on intestinal bacteria during incubation in selective media as explained below. The term growth capacity should therefore be viewed as the growth potential of a group of bacteria in an intestinal sample.

The authors acknowledge the fact that the method was unable to calculate original cell counts of the samples. However, cell counts such as CFU are also biased by the same factors (nonhomogeneous extraction and distribution of bacteria in samples and inadequate nutrient composition of media). Furthermore, calculation of CFU is based on the assumption that each colony originates from a single bacterium. As mentioned above, this can not be assumed for samples from the intestinal tract.

\section{Total anaerobic growth}

The devclopment of total anaerobic growth in samples from probiotic-supplemented piglets was slightly influenced by weaning. Intestinal segments distal to the duodenum displayed very similar growth before weaning, but growth increased in the large intestine after weaning. The probiotic was present in samples from the piglets fed probiotic and may have influenced growth of other bacteria during the incubation period. Comparison with $B$. cereus var. toyoi $\mathrm{CFU}$ from mucosal samples (Jadamus et al., 1998b) shows that the large intestine is continuously colonized by the probiotic as early as $\mathrm{d} 13$ of age, although total CFU were low $\left(10^{3}-\right.$ $10^{5} \mathrm{CFU} / \mathrm{g}$ mucosa). Most Bacillus spp. are fast growing bacteria with simple nutrient requirements, comparable to in vitro growth of enterobacteria. $B$. cereus var. toyoi grows well in the complex nutrient broth even under anacrobic conditions and thus, significant growth may have occurred. However, rapid growth of the probiotic during incubation is unlikely, because the control group displayed cqual or higher turbidity readings in the same nutrient broth throughout the trial period.

Comparison of total anaerobic growth in small intestinal segments shortly before weaning indicates that the probiotic was able to „buffer" the quantity of microbial populations against changing environmental conditions, cither in vivo or in vitro during incubation. Although there is no evidence that qualitative changes in microbial composition have occurred in probiotic-treated animals, the steady in- 
crease in growth suggests a gradual succession of bacterial populations rather than the drastic changes observed in the upper intestinal tract of the control group. This probiotic mechanism has often been defined as ,stabilizing” (Fuller 1989; 1992; Seifert and Gessler, 1996). The term stabilizing implies that probiotic-free animals develop unstable microbial populations, in which succession and quantity of bacteria develop at random. However, challenge and feeding trials show that rather large amounts of pathogenic bacteria (Fox, 1988) or nutrient deficient feeds (Spicler and Männer, 1996) are needed to invoke an outbreak of disease even in young animals with yet undeveloped microbial populations (Tournut, 1989; Kelly, 1998). Thus, stable populations can also be found in probiotic-free animals and the term stabilizing may be misleading. The authors favour the term „buffering capacity” for the following reasons: it is unlikely that one bacterial strain has the capability to influence all intestinal bacteria by direct means, thus secondary effects (microbial composition, host response, etc.) are more likely; the stabilization of the microbial status quo would not be beneficial especially for young piglets, as nutrient conditions change rapidly. Therefore, the influence of the probiotic on microbial populations should be viewed as an additional buffer against possible negative effects from specific bacteria.

\section{Lactic acid bacteria and enterococci}

The nutrient broth for enrichment of $\mathrm{LAB}$ supports growth of the probiotic, but not to the extent as the broth for the anaerobic bacteria. Thus, in vitro growth effects of the probiotic were unlikely for the LAB broth.

Rapid colonization of LAB takes place in the newborn animal and leads to numerical domination of these bacteria in the upper intestinal tract (Smith and Jones, 1963). Unlimited growth is then restricted by increasing the immune response from the host and increasing bacterial competition (Savage, 1977). Maximum possible bacterial cell densities in the mucosa of suckling piglets were probably present before the time of the first sampling at $d 13$ of age, because there was a decrease in growth on subsequent sampling days. The composition of epithelial tissues is also modificd as the newborn animal adapts to nutrient quality and increased feed uptake (Smith et al., 1985; Hampson, 1986; Moré et al., 1987; Zhang et al., 1998). The decline in LAB growth capacities during the suckling period may be viewed as the adjustment of LAB populations to these changes.

\section{Enterobacteria}

Colonization of the gastrointestinal tract of piglets with microorganisms starts shortly after farrowing by contact with the sow and a microorganism-contaminated environment. During the development of the gastrointestinal tract of young 
piglets, microbial multiplication varies depending on their need for specific environmental growth conditions (Smith, 1965).

The drastic reduction of bacterial growth in suckling piglets is unlikely due to direct probiotic effects, because only probiotic-contaminated faeces from the probiotic fed sow were available. Colonization of B. cereus var. toyoi in suckling piglets is limited to the large intestine and the total amount of the probiotic in the small intestine is negligible in the first threc wecks of life (Jadamus et al., 1998b). Therefore, reduced growth for enterobacteria was possibly due to the intake of intestinal microorganisms from faeces of the sow. These microbial populations may have been influenced by the probiotic-supplemented fced. The homogeneous and less intensive growth of entcrobacteria throughout the intestinal tract before uptake of the probiotic can be viewed as a constant suppression by probiotic-influenced microbial populations from the sow. Thus, the buffering effect of $B$. cereus var. toyoi on indigenous bacteria from sow faeces might have controlled growth in the first three weeks of life.

\section{CONCLUSIONS}

Bacterial growth in mucosal tissues from piglets was influenced by $B$. cereus var. toyo $i$-supplemented feed. Total anaerobic bacteria, enterobacteria and Enterococci showed heterogencous growth in samples from the intestine of non-probiotic fed piglets, while ToyoCerin-supplemented feed led to more homogeneous growth in all intestinal segments. Growth of mucosa-associated enterobacteria was reduced $(\mathrm{P}<0.05)$ in suckling piglets before uptake of $B$. cereus var. toyoi-supplemented feed. The probiotic may thus influence intestinal microbial populations of the sow, which are conferred to the piglets by contact with faeces from the sow.

\section{ACKNOWLEDGEMENT}

The authors wish to thank Prof. Klaus Männer for animal and trial management. Sybille Weinholz is thanked for technical assistance. 


\section{REFERENCES}

Andrews J.H., 1998. Bacteria as modular organisms. Annu. Rev. Microbiol. 52. 105-126

Costerton J.W., Stewart P.S.. Greenberg E.P., 1999. Bacterial biofilms: a common cause of persistent infections. Science 284, 1318-1322

Davies D.G., Parsek M.R., Pearson J.P., Iglewski B.H., Costerton J.W.. Greenberg E.P., 1998. The involvement of cell-to-cell signals in the development of a bacterial biofilm. Science 280 , 295-298

Fox S.M., 1988. Probiotics: intestinal inoculants for production animals. Vet. Med. 8, 806-830

Fuller R., 1989. Probiotics in man and animals. J. Appl. Bacteriol. 66, 365-378

Fuller R. (Editor), 1992. Probiotics. The Scientific Basis. Chapman and Hall, London, pp. 1-8

Fuller R., 1999. Probiotics for farm animals. In: G.W. Tannock (Editor). Probiotics: A general Review. 17, Horizon Scientific Press, Wymondham, (UK), pp. 15-22

Gerhardt P., Drew S.W., 1994. Liquid culture. In: P. Gerhardt, R.G.E. Murray, W.A. Wood, N.R. Krieg (Editors). Methods for General and Molecular Bacteriology. Amer. Soc. Microbiol. Washington. DC, pp. 224-247

Hampson D.J., 1986. Alterations in piglet small intestinal structure at weaning. Res. Vet. Sci. 40. $32-40$

Hattori Y., Watanabe N., 1981. Effect of Administration of Bacillus toyoi on the Intestinal Bacterial Flora in Pigs. Toyo Jozo Co., Ltd., Tokyo

Holt J.G., Krieg N.R., 1994. Enrichment and isolation. In: P. Gerhardt, R.G.E. Murray, W.A. Wood, N.R. Krieg (Editors). Methods for General and Molecular Bacteriology. Amer. S. Microbiol., Washington, DC. pp. 179-182

Iben Ch., Leibetseder J.. 1989. Untersuchungen der leistungsfördernden Wirkung von Toyocerin in der Ferkelaufzucht. Wien. Tierärztl. Monatsschr. 76, 363-366

Jadamus A., Vahjen W., Simon O.. 1998a. Wachstumsverhalten eines sporenbildenden probiotischen Futterzusatzes im Verdauungstrakt von Broilern. Proc. Nutr. Soc. Physiol. 7, 106

Jadamus A., Vahjen W., Simon O., 1998b. Wachstumsverhalten eines sporenbildenden probiotischen Futter7usatzes im Verdauungstrakt von Ferkein. 5. Tagung Schweine- und Geflügelernährung. Wittenberg (Germany), pp. 105- 108

Kahrs D., 1986. ToyoCerin, ein Weg zur Stabilisierung der Darmllora. Kraftfutter 69 (9), 364-370

Kelly D., 1998. Probiotics in young and newborn animais. J. Anim. Feed Sci. 7, Suppl. 1, 15-23

Knutton S., Shaw R.K., Anantha R.P., Donnenberg M.S., Zorgani A.A., 1999. The type IV bundleforming pilus of enteropathogenic Escherichia coli undergoes dramatic alterations in structure associated with bacterial adherence, aggregation and dispersal. Mol. Microbiol. 33, 499-509

Klaver F.A.M., Van der Meer R., 1993. The assumed assimilation of cholesterol by lactobacilli and Bifidobacterium bifidum is due to their bile salt-deconjugating activity. Appl. Environ. Microbiol. 4. $1120-1124$

Morć J., Fioramonti J., Bénazet F., Bue'no L., 1987. Histochemical characterisation of glycoproteins present in jejunal and colonic goblet cells of pigs on different diets. Histochemistry 87. 189-194

Morishita Y., Ogata M., 1970. Studies on the alimentary flora of pig. V. Influence of starvation on the microbial flora. Jpn J. Microbiol. 15, 531-538

Naito S., Hayashidani H., Kaneko K., Ogawa M., Benno Y., 1995. Development of intestinal lactobacilli in normal piglets. J. Appl. Bacteriol. 79, 230-236

Nemcova R., Laukova A., Gancarcikova S., Kastel R., 1997. In vitro studies of porcine lactobacilli for possible probiotic use. Berl. Mun. Tierärztl. Wochenschr. 110, 413-417

Nousiainen J., Setälä J., 1993. Lactic acid bacteria as animal probiotics. In: S. Salminen, A, von Wright (Editors). Lactic Acid Bacteria. Marcel Dekker, Inc., New York, pp. 315-356 
Rojas M., Conway P.L., 1996. Colonisation by lactobacilli of piglet small intestinal mucus. J. Appl. Bacteriol. 81, 474-480

Savage D.C.. 1977. Microbial ecology of the gastrointestinal tract. Annu. Rev. Microbiol. 31. 107-133

Seifert H.S.H., Gessler F., 1996. Orale Daucrapplikation des probiotischen B. cereus- eine Alternative zur Verhütung der Enterotoxamic? Deut. Tierär7tl. Wochenschr. 103. 386-389

Smith H.W., 1965. Observations on the flora of the alimentary tract of animals and factors affecting its composition. J. Pathol. Bacteriol. 89, 95-122

Smith H.W. Jones J.E.T., 1963. Observation on the alimentary tract and its bacterial flora in healthy and discased pigs. J. Pathol. Bacteriol. 89, 387-412

Smith M.W., Miller B.G., James P.S., Bourne F.J., 1985. Effect of weaning on the siructure and function of piglet small intestine. Proceedings of the 3rd International Seminar on Digestive Physiology in the Pig. Copenhagen, pp. 75-78

Spieler A., Männer K., 1996. Milchsäurebakterien als probiotischer Futterzusatzstoff. Tier und Ernähr. 3. Roche, $1-5$

Tournut J., 1989. Applications of probiotics to animal husbandry. Rev. Sci. Tech. Oic. 8, 551-566

Van der Mei H.C., Cox S.D., Geertsema-Doornbusch G.I., Doyle R.J., Busscher H.J.. 1993. A critical appraisal of positive cooperativity in oral streptococcal adhesion: Scatchard analyses of adhesion data versus analyses of the spatial arrangement of adhering bacteria. J. Gen. Microbiol. $139,937-948$

Wadstrom T., Andersson K., Sydow M., Axelsson L., Lindgren S., Gullmar B., 1987. Surface properties of lactobacilli isolated from the small intestine of pigs. J. Appl. Bacteriol. 62, 513-520

Wibawan I.T., Lammler C., Pasaribu F.H., 1992. Role of hydrophobic surface proteins in mediating adherence of group B streptococci to cpithelial cells. J. Gen. Microbiol. 138, 1237-1242

Zhang H., Malo C.. Boyle C.R., Buddington R.K., 1998. Diet influences development of the pig (Sus scrofa) intestinc during the first 6 hours after birth. Amer. Soc. Nutr. Sci. 8. 1302-1310

\section{STRESZCZENIE}

\section{Wpływ probiotycznego szczepu bakterii, Bacillus cereus var. toyoi, na rozwój wybranych grup bakterii przylegających do jelita prosiąt}

Badano wpływ probiotycznego szczepu bakterii, Bacillus cereus var. toyoi, na rozwój beztlenowców, enterobakterii, bakterii kwasu mlekowego oraz gatunku Enterococcus, związanych ze śluzówką jelita prosiąt, przed i wkrótce po odsadzeniu. Wzrost bakterii oznaczano na płytkach do mikro miareczkowania po inkubacji ekstraktu śluzówki w selektywnych płynnych mediach dla enterobakterii, bakterii kwasu mlekowego (LAB), gatunku Enterococcus lub suny beztlenowców.

Wzrost enterobakterii związanych ze śluzówką był mniejszy $(P<0.05)$ w próbach pobranych od prosiąt grup doświadczalnych przed ođsadzeniem. Ponadto wzrost był podobny we wszystkich próbach, podczas gdy wzrost enterobakterii z grupy kontrolnej zwiększał się w miarę zbliżania siç do jelita grubego. Rozwój beztlenowców był podobny jak enterobakterii. Mniejszy wzrost stwierdzono w próbach pobranych z jelita cienkiego prosiąt kontrolnych, odsadzonych w 28 dniu życia. Wzrost gatunku Enterococcus i LAB zmniejszał się od 13 dnia życia prosiąt i gwałtownie zwiększał się po odsadzeniu, niczależnic od dodatku probiotyku.

W podsumowaniu stwierdzono, że B. cereus var. toyoi hamuje wzrost enterobakterii w przewodzie pokarmowym. Wykazano, że wczesne podawanie uprzednio zmodyfikowanej populacji drobnoustrojów z kału maciory pomaga w ustaleniu podobnej populacji drobnoustrojów u prosiąt. 